\title{
Deregulasi Sektor Moneter dan Kebijaksanaan Uang Ketat
}

\section{PENDAHULUAN}

Kebijaksanaan Moneter, demikian juga Kebijaksanaan Fiskal, yang dijalankan oleh Otoritas Moneter suatu negara mempunyai sasaran akhir/final target dalam jangka pendek untuk menjaga keseimbangan yang ideal suatu perekonomian yang meliputi :

- tercapainya laju inflasi yang rendah.

- tingkat kegiatan ekonomi yang tinggi.

- Neraca Pembayaran yang seimbang.

Untuk mencapai sasaran akhir tersebut tidaklah mudah dan dibutuhkan waktu yang panjang. Dengan demikian ada jarak waktu antara tindakan kebijaksanaan moneter dengan pengaruhnya pada ketiga aspek sasaran akhir. Jarak waktu itu dikenal sebagai Time Lag.

Kebijaksanaan moneter secara luas mengkaji beberapa masalah penting. Diantaranya ada dua masalah yang berkaitan dengan kebijaksanaan uang ketat yang dewasa ini sedang dijalankan oleh Otoritas Moneter kita. Adapun dua masalah tersebut adalah masalah penentuan sasaran antara atau intermediate target, dalam hal ini ada dua alternatif yaitu tingkat bunga dan jumlah uang yang beredar.

Masalah kedua berkaitan dengan pilihan tentang konsep uang beredar yang mana yang terbaik sebagai sasaran antara. Alternatifnya adalah Narrow Money (M1), Broad Money (M2), Primary Money (B), dan Total Liquiditiy (L).

Pentingnya menentukan sasaran antara adalah untuk mengantisipasi adanya time lag dalam proses memberlakukan kebijaksanaan sampai dapat terlihat pengaruh hasil kebijaksanaan tersebut. Oleh karena itu, sasaran antara berfungsi sebagai indikator awal untuk melihat kecenderungan atas situasi yang diharapkan terjadi dengan diberlakukannya suatu kebijaksanaan moneter. Sebagai indikator awal, sasaran antara harus reliable (cukup 
akurat dan andal) dan harus segera dapat diamati dan dimonitor.

Dalam bidang moneter kita dapat melihat hubungan antara jumlah uang yang beredar dengan tingkat bunga, inflasi dan laju pertumbuhan ekonomi secara keseluruhan. Oleh karena pentingnya fungsi uang sebagai produk perbankan, antara lain :

- sebagai alat pembayaran dalam perniagaan.

- sebagai alat pengukur nilai barangbarang dan jasa-jasa, serta

- sebagai alat penyimpan kekayaan untuk masa mendatang,

maka diperlukan usaha-usaha untuk mengatur peredarannya dengan tepat sehingga dapat menunjang kegiatan perekonomian secara positip.
Terdapat beberapa cara untuk mengukur jumlah uang yang beredar, yaitu melalui pengaturan. jumlah M1 (uang kartal dan uang giral), karena jenis uang tersebut paling banyak digunakan dalam transaksi perniagaan (hal itu berkaitan dengan fungsi uang sebagai medium of exchange/alat pertukaran).

Disamping itu, pengukuran jumlah uang yang beredar dapat juga dilakukan melalui pengaturan M2, (yang terdiri dari M1 ditambah simpanan berjangka dan berbagai macam tabungan masyarakat pada bank-bank (fungsi uang sebagai liquid asset).

Berikut ini disajikan tabel jumlah M1 dan M2 untuk tahun 1985 sampai dengan tahun 1989,

Tabel 1 : Jumlah M1 dan M2 (dalam milyar rupiah)

\begin{tabular}{l|r|r|r|r|r|r|c}
\hline \hline Tahun & Kartal & Giral & $\begin{array}{l}\text { Jumlah } \\
\text { M1 }\end{array}$ & $\begin{array}{c}\text { Perub. } \\
(\%)\end{array}$ & $\begin{array}{c}\text { Uang } \\
\text {. Kuasi }\end{array}$ & $\begin{array}{c}\text { Jumlah } \\
\text { M2 }\end{array}$ & $\begin{array}{c}\text { Perub. } \\
(\%)\end{array}$ \\
\hline 1985 & 4.440 & 5.664 & 10.104 & 17 & 13.049 & 23.153 & \\
1986 & 5.338 & 6.339 & 11.677 & 15 & 15.984 & 27.661 & 20 \\
1987 & 5.782 & 6.903 & 12.685 & 9 & 21.200 & 33.885 & 23 \\
1988 & 6.246 & 8.146 & 14.392 & 13 & 27.606 & 41.998 & 24 \\
1989 & 7.426 & 12.688 & 20.114 & 39 & 38.591 & 58.705 & 40 \\
& & & & & & & \\
\end{tabular}

Sumber : Bank Indonesia 
Kemudian tabel berikut menunjukkan jumlah M1 nominal, M2 riel, laju pertumbuhan ekonomi dan tingkat inflasi dari tahun 1985 sampai dengan tahun 1989, perkembangan jumlah uang tidak berpengaruh besar terhadap inflasi (lihat Jumlah M1 dan Tingkat Inflasi), atau berarti ada faktor-faktor lain yang lebih berpengaruh terhadap

Tábel 2 : Jumlah M1 Nominal, M2 Riel, Laju Pertumbuhan Ekonomi dan Tingkat Inflasi.

\begin{tabular}{c|c|c|c|c|c|c}
\hline \hline Tahun & $\begin{array}{c}\text { M1 Nominal } \\
\text { (milyar rp.) }\end{array}$ & IHK & $\begin{array}{c}\text { M2 Riel } \\
\text { (milyar } \\
\text { rp.) }\end{array}$ & Inflasi & \multicolumn{2}{|c}{$\begin{array}{c}\text { Laju Pertumbuhan } \\
\text { Ekonomi (\%) }\end{array}$} \\
\cline { 4 - 7 } & & & $\begin{array}{c}\text { Harga } \\
\text { Berlaku }\end{array}$ & $\begin{array}{c}\text { Harga } \\
\text { Konstan }\end{array}$ \\
\hline 1985 & 10.104 & 252 & 4.010 & 4,31 & 7,9 & 2,5 \\
1986 & 11.677 & 275 & 4.246 & 8,83 & 5,9 & 5,9 \\
1987 & 12.685 & 301 & 4.214 & 8,90 & 21,5 & 4,9 \\
1988 & 14.392 & 318 & 4.526 & 5,47 & 12,0 & 5,7 \\
1989 & 20.114 & 337 & 5.969 & 5,97 & 17,1 & 7,4 \\
\hline
\end{tabular}

Sumber : Bank Indonesia dan Biro Pusat Statistik

Dalam tabel 1, terlihat perkembangan M1 menurun pada tahun 1985 sampai dengan tahun 1987, kemudian meningkat lagi pada tahun 1988 dan tahun 1989 terdapat kenaikan yang tinggi yaitu $39 \%$. Sementara itu perkembangan M2 selalu meningkat. Terlihat juga peranan Uang Kuasi yang dominan, dimana jumlah uang kuasi lebih besar daripada jumlah M1. Disamping itu uang kuasi sebagai bagian dari $\mathbf{M} 2$, merupakan danadana yang relatif mahal bagi investor untuk membiayai kegiatan 'mereka. Hal itu disebabkan adanya biaya penghimpunan uang kuasi dari masyarakat berupa tingkat bunga yang menarik.

Dalam tabel 2, terlihat bahwa pertumbuhan M1 nominal mencerminkan kenaikan tingkat harga (IHK), tetapi kenyataannya menunjukkan bahwa tingkat inflasi, karena jumlah uang yang beredar hanyalah salah satu aspek dari beberapa aspek penyebab inflasi.

Untuk tahun 1989 terlihat kenaikan M1 yang tinggi yaitu $39 \%$, tetapi kenaikan inflasinya relatif kecil yaitu $0,50 \%$, hal itu dapat diartikan bahwa suplai uang relatif seimbang dengan permintaannya karena diikuti dengan suplai komoditi yang dibutuhkan oleh pasar.

Kemudian kalau dilihat laju pertumbuhan ekonominya ternyata cukup tinggi yaitu $17,1 \%$ pada harga konstan dan $7,4 \%$ pada harga berlaku, ini menunjukkan adanya kegiatan produktif yang tinggi, atau suplai uang telah dimanfaatkan untuk kegiatan yang bersifat produktif. 


\section{DEREGULASI SEKTOR MONETER.}

Rangkaian deregulasi yang dilakukan oleh Pemerintah Indonesia tidak lepas dari usaha untuk mencapai sasaran akhir dari kebijaksanaan moneter. Deregulasi yang diberlakukan itu meliputi deregulasi dan liberalisasi, yang menurut Waterson, pengertian deregulasi adalah merupakan pengurangan aturan maupun kendala yang ditetapkan oleh Pemerintah untuk mempengaruhi kegiatan dunia usaha, sedangkan liberalisasi diartikan sebagai pengendoran atas berbagai pembatasan yang mengatur pendirian usaha baru untuk masuk pada suatu cabang kegiatan ekonomi (market entry).

Deregulasi menurut pengertian. tersebut, telah dilakukan oleh Pemerintah dalam bentuk penyederhanaan peraturan-peraturan prosedural dan mengurangi birokrasi perijinan usaha yang biasa disebut dengan debirokratisasi. Sedangkan liberalisasi telah dipraktekkan dalam wujud dibukanya kesempatan mendirikan bank baru, perluasan kantor cabang di berbagai daerah dan pendirian bank campuran antara swasta nasional dengan perusahaan asing serta pembukaan kantor cabang bank asing di luar wilayah Jakarta.

Terdapat beberapa alasan mengapa deregulasi perlu dilakukan. Menurut Savas, alasan-alasan tersebut adalah meliputi hal-hal berikut ini :

- Alasan Pragmatis,

yaitu apabila Pemerintah mengalami kesulitan anggaran, maka perlu dilakukan pengurangan kegiatan negara dan peningkatan efisiensi dan produktivitas badan usaha milik negara (BUMN) dengan sasaran untuk mendorong sektor negara ke arah yang lebih baik sehingga mam pu mendukung perekonomian negara secara lebih positip. Dengan kata lain adalah untuk menciptakan kondisi perekonomian yang tidak terlalu tergantung kepada anggaran negara.

- Alasan Ideologi, yaitu usaha untuk mengurangi peranan sektor negara yang berlebihan dalam kehidupan masyarakat apabila peranan sektor negara dianggap terlalu dominan, dimana dalam sektor negara ini, pengambilan keputusan lebih banyak mendasarkan diri pada halhal yang bersifat politis, sehingga sedikit banyak mengabaikan efisiensi ekonomi melalui mekanisme pasar.

- Alasan Komersial, yaitu alasan dimana diharapkan lebịh banyak kegiatan ekonomi yang diserahkan kepada sektor swasta terutama bidang kegiatan yang tidak menyangkut hajat hidup orang banyak. Sasarannya adalah dicapainya efisiensi yang tinggi oleh swasta, karena sektor negara kurang efisien.

- Alasan Populis, yaitu alasan untuk memberikan kebebasan yang lebih besar kepada masyarakat untuk mengurus dirinya sendiri dengan mengidentifikasi kebutuhan dan sekaligus menienuhinya sendiri.

\section{A. Peranan Sektor Moneter}

Peranan sektor moneter yang mencakup industri keuangan dalam 
perekonomian nasional sangat penting karena dari sektor moneter (industri keuangan) inilah dana-dana untuk pembiayaan pembangunan diakumulasi untuk kemudian dialokasikan kepada sektor-sektor lainnya. Mengingat begitu pentingnya peran industri keuangan tersebut maka diperlukan upaya-upaya khusus untuk menangani industri ini.

Terdapat beberapa alasan mengapa industri keuangan perlu diatur lebih ketat daripada industri lainnya yaitu :

- untuk menjaga keamanan serta kesehatan lembaga keuangan maupun kesehatan sistem keuangan secara keseluruhan, hal ini berkaitan erat dengan fungsi uang sebagai alat pertukaran dan fungsi-fungsi lainnya.

- untuk dapat mengontrol stok (persediaan) jumlah uang yang beredar dalam menjaga stabilitas tingkat harga-harga, hubungannya dengan fungsi industri keuangan (bank) sebagai lembaga pencipta uang.

- adanya anggapan bahwa industri keuangan berbeda dengan industri lainnya. Industri kèuangan dianggap sebagai industri yang sangat strategis dalam mengalokasikan sumbersumber ekonomi untuk mewujudkan berbagai sasaran pembangunan nasional.

- untuk memelihara terjadinya persaingan yang sehat dalam industri keuangan, berkaitan dengan tugas perbankan untuk memobilisasi dana masyarakat melalui berbagai produk perbankan, kemudian upaya pencapaian biaya intermediasi yang ekonomis serta penekanan tingkat piutang ragu-ragu atau kredit macet. Sasarannya adalah meningkatkan efisiensi industri keuangan sehingga pada akhirnya memberikan kontribusi yang besar terhadap efisiensi kegiatan perekonomian secara keseluruhan.

B. Paket Paket Kebijaksanaan Moneter Yang Penting.

1. Kebijaksanaan Moneter 1 Juni 1983 (Deregulasi Juni 1983).

Kebijaksanaan ini merupakan awal dari rangkaian kebijaksanaan moneter/deregulasi moneter yang dilakukan oleh Pemerintah khususnya yang menyangkut dunia perbankan nasional.

Deregulasi ini berisi pokok-pokok penting sebagai berikut :

- Penghapusan pagu kredit perbankan, berarti tidak ada lagi batas-batas atau plafon besarnya kredit yang boleh disalurkan, perbankan bebas menentukan sendiri.

- Pembebasan penentuan tingkat bunga, (kecuali kredit prioritas), berarti perbankan, boleh menentukan besarnya tingkat bunga sesuai dengan perhitungan ekonomisnya.

- Penurunan kredit likuiditas (hanya untuk program prioritas), berarti perbankan harus meningkatkan efisiensi usahanya karena kredit yang relatif murah itu sedikit demi sedikit diturunkan.

Kemudian setelah deregulasi ini pengaturan jumlah uang yang beredar tidak lagi secara langsung melalui pagu kredit, kredit 
likuiditas dan penetapan tingkat bunga, tetapi berubah menjadi secara tidak langsung melalui politik pasar terbuka (open market policy), fasilitas diskonto (discount window) serta cadangan minimum (reserve requirement).

- politik pasar terbuka dilakukan melalui instrumen Sertifikat Bank Indonesia atau SBI dan Surat Berharga Pasar Uang atau SBPU yang diperkenalkan mulai tahun 1984/1985, untuk mempengaruhi jumlah uang yang beredar SBI dan SBPU diperjualbelikan oleh Bank Indonesia kepada bank-bank.

- fasilitas diskonto membantu perbankan yang mengalami kesulitan likuiditas, seperti kalah dalam kliring, akibat mismatch dalam pengaturan dan penyaluran dana yang dihimpun.

- Cadangan minimum sebesar $15 \%$, artinya jumlah dana yang berhasil dihimpun oleh satu bank tidak boleh dialokasikan seluruhnya melainkan harus dicadangkan sebesar $15 \%$ untuk berjaga-jaga.

2. Paket Kebijaksanaan 27 Oktober 1988 (Pakto 27 tahun 1988).

Kebijaksanaan/deregulasi ini merupakan kelanjutan dari deregulasi 1 Juni 1983, yang memuat isi pokok antara lain :

- Menurunkan cadangan minimum (reserve requirement) dari sebelumnya sebesar $15 \%$ menjadi hanya $2 \%$, termasuk deposito berjangka dan tabungan, hal ini berarti peluang mengalokasikan dana yang terhimpun bertambah besar.
- Kemudahan mendirikan bank baru, serta :mendorong bankbank untuk mengeluarkan produk-produk perbankan yang baru atau diversifikasi produk perbänkan.

- Memperingan syarat pendirian bank devisa, hal ini ditujukan untuk lebih memperlancar arus transaksi devisa (mendorong kredit ekspor).

- Mengijinkan pendirian bank campuran dan cabang bank asing di luar Jakarta sehingga diharapkan merangsang investor asing untuk menanam investasi di daerah.

- Sebagian dana Badan Usaha Milik Negera/BUMN dapat ditempatkan pada Bank Umum Swasta Nasional/BUSN dan Lembaga Keuangan Bukan Bank/LKBB, ini dapat mendorong gairah usaha BUSN dan LKBB dengan lebih baik.

- Menetapkan batas maksimum pemberian kredit kepada kelompok debitur/legal lending limit artinya ada pembatasan jumlah kredit oleh suatu bank kepada debitur yang termasuk dalam satu kelompok usaha dengan bank tersebut hal ini dimaksudkan untuk mengantisipasi praktekpraktek perbankan yang tidak sehat.

- Perpanjangan transaksi SWAP dari 6 bulan menjadi 3 tahun serta penentuan premi atas dasar bunga deposito.

- Pembatasan posisi devisa neto, yaitu selisih antara aktiva dan pasiva dalam valuta asing, sebesar $25 \%$. dari modal sendiri. : 
3. Paket Kebijaksanaan 20 Desember 1988 (Pakdes 20 tahun 1988)

Kebijaksanaan/deregulasi ini melengkapi paket kebijaksanaan

27 Oktober 1988 (Pakto 27), dimana isinya yang pokok mengenai ketentuan usaha Lembaga Keuangan Bukan Bank (LKBB) dan Pasar Modal atau Bursa Efek.

4. Paket Kebijaksanaan Januari 1990 (Pakjan 1990)

Kebijaksanaan/deregulasi ini dimaksudkan untuk. mendorong kemandirian perbankan serta sasaran pemerataan. Beberapa isi pokok dari paket ini adalah sebagai berikut :

- Kredit Likuiditas Bank Indonesia (KLBI) ditarik secara bertahap, dan lebih diarahkan kepada kredit pengadaan pangan, kredit pengembangan koperasi dan kredit investasi.

- Perbankan dikenakan kewajiban menyalurkan portofolio kreditnya sebesar $20 \%$ untuk Kredit Usaha Kecil (KUK), hal ini merupakan komitmen pemerataan yang harus dilaksanakan oleh dunia perbankan kepada dunia usaha skala kecil.

Dari paket-paket kebijaksanaan moneter tersebut terr" ${ }^{n}$ in tekad Pemerintah yang sun $\varepsilon_{,}, \lambda$-sungguh untuk selalu meningkatkan kegiatan perekonomian melalui berbagai cara. Sasaran yang ingin dicapai adalah laju pertumbuhan ekonomi yang tinggi sehingga dapat menciptakan sekaligus menampung lapangan kerja baru bagi angkatan kerja yang semakin besar, serta dapat mewujudkan pemerataan pendapatan masyarakat dengan lebih baik.

\section{DAMPAK DEREGULASI SEKTOR MONETER.}

Salah satu tujuan kebijaksanaan Pemerintah melalui Pakto-27 maupun Pakdes-20 adalah meningkatkan mobilisasi tabungan masyarakat. Latar belakang tindakan tersebut adalah penurunan tingkat harga minyak bumi dan meningkatnya beban pembayaran utang luar negeri (dengan demikian deregulasi ini lebih didorong oleh alasan pragmatis). Keadaan itu mendorong Pemerintah melakukan

kebijaksanaankebijaksanaan sebagai berikut :

- Kebijaksanaan mengencangkan ikat pinggang dengan jalan menurunkan pengeluaran konsumsi dan investasi masyarakat serta pengeluaran negara.

- Restrukturalisasi perekonomian untuk meningkatkan produktivitas, efisiensi dan daya saing perekonomian nasional di pasar dunia.

- Meningkatkan tabungan nasional baik berupa Rupiah maupun Valuta Asing.

Sebagai akibat diberlakukannya rangkaian kebijaksanaan moneter/deregulasi moneter oleh Pemerintah maka timbullah dampak deregulasi yang antara lain sepperti berikut ini,

A. Penambahan Jumlah Bank dan Kantor Cabangnya.

Dengan dipermudahnya persyaratan mendirikan bank meialui 
Pakto-27, maka akibatnya bermunculanlah bank-bank baru, maupun perluasan kantor-kantor cabang dari bank yang sudah ada.

Pada tahun 1989 jumlah bank sebanyak 111 buah dengan kantor cabang sebanyak 1879 buah, kemudian pada tahun 1990 jumlah tersebut berkembang menjadi 151 buah untuk bank dan 2.841 untuk kantor cabang. Jumlah-jumlah tersebut belum termasuk Bank Perkreditan Rakyat (BPR) yang jumlahnya lebih banyak lagi.

Dengan semakin banyaknya jumlah bank dan kantor cabangnya maka akan mengakibatkan meningkatnya kemampuan perbankan dalam menghimpun dana dari masyarakat.

B. Penambahan Produk dan Jasa Layanan Perbankan.

Jumlah bank yang semakin banyak menyebabkan makin ketatnya persaingan pada industri tersebut. Hal itu mendorong masing-masing bank untuk semakin kreatif dan inovatif dalam menjalankan operasinya. Bentuk persaingan tersebut dapat dilihat dari munculnya beraneka macam produk perbankan yang baru, yang masing-masing menawarkan kemudahan/fasilitas dan tingkat bunga yang menarik serta iming-iming undian berhadiah yang menggiurkan, contoh hasil kreasi dan inovasi perbankan seperti Tahapan, Taplus, Tapres, Kesra, Jumbo, Simpedes Demuna, Primadollar, Kupedes, Home Loan, Car Loan dan lain-lainnya.
C. Mobilisasi Dana Masyarakat.

- Dana masyarakat yang berhasil dimobilisasi oleh perbankan meningkat sangat pesat. Bank Umum Swasta Nasional saja berhasil menghimpun dana masyarakat sebesar Rp. 47.306,6 milyar yang terdiri dari Giro sebesar Rp. 12.528,3 milyar, Deposito sebesar Rp. 31.093,6 milyar dan Tabungan sebesar Rp. 3.684,7 milyar, jumlah. tersebut adalah per September 1990.

- Sedangkan total dana masyarakat yang berhasil dihimpun per Desember 1989 mencapai jumlah Rp. 54,8 trilyun, yang berarti mengalami kenaikan sebesar $46,7 \%$ dari tahun sebelumnya.

- Dari sisi kredit, perbankan berhasil menyalurkan kredit sebesar Rp. 54.241 milyar per Desember 1988, kemudian meningkat menjadi Rp. 93.372 milyar per April 1990, berarti terdapat kenaikan $72,14 \%$ selama 16 bulan.

- Pada periode 1983-1989 terdapat kenaikan rata-rata jumlah deposito sebesar $25 \%$, sedangkan kenaikan rata-rata jumlah kredit untuk periode yang sama adalah sebesar $21 \%$.

- Disamping mobilisasi dana masyarakat melalui sektor perbankan juga terjadi penghimpunan dana masyarakat melalui Pasar Modal. Hal itu tercermin dari banyaknya perusahaan-perusahaan besar yang melakukan Go Public dengan menjual sebagian sahamnya kepada masyarakat. Jumlah kapitalisasi dari perusahaan yang Go 
Public secara keseluruhan juga sangat besar, sedangkan dana kapitalisasi ini termasuk kategori dana yang sangat murah untuk saat ini dibandingkan jika mereka mendapatkan dana tersebut melalui bank.

- Mobilisasi dana masyarakat sangat berpengaruh terhadap jumlah uang yang beredar di masyarakat dan juga menyumbang terhadap tingkat inflasi seperti terlihat pada tabel berikut : modal. Sayangnya adalah bahwa peningkatan permintaan itu tidak diikuti oleh sektor riil secara proporsional. Akibatnya adalah meningkatnya tingkat inflasi, yang juga disebabkan oleh sebab-sebab lain berupa kebijaksanaan penyesuaian seperti kenaikan ga$\mathrm{ji}$, kenaikan harga BBM, kenaikan tarip listrik, inflasi luar negeri akibat krisis Teluk. Naiknya tingkat inflasi sampai sebesar 9,47 persen per Nopember 1990, cukup

Tabel 3 : Jumlah Uang Beredar dan Inflasi.

\begin{tabular}{c|c|c}
\hline Tahun. & $\begin{array}{c}\text { Jumlah Uang Beredar } \\
\text { (milyar rp.) }\end{array}$ & $\begin{array}{c}\text { Tingkat Inflasi } \\
(\%)\end{array}$ \\
\hline & 10.104 & \\
1985 & 11.677 & 4,31 \\
1986 & 12.685 & 8,83 \\
1987 & 14.392 & 8,90 \\
1988 & 20.114 & 5,47 \\
1989 & $23.077^{*}$ & 5,97 \\
1990 & & $9,47 @$ \\
\hline
\end{tabular}

* per September : @ per Nopember

Sumber : Bank Indonesia dan Biro Pusat Statistik.

Sampai dengan bulan Desember 1990 inflasinya mencapai $9,57 \%$ (kurang dari 10\%).

D. Dampak Mobilisasi Dana mengkhawatirkan Pemerintah Masyarakat. karenanya diusahakan untuk

Meningkatnya likuiditas dan mobilisasi dana masyarakat, disebabkan naiknya aktivitas perbankan, mengakibatkan lebih lanjut berupa naiknya permintaan agregat. Kenaikan permintaan tersebut juga disebabkan oleh naiknya investasi luar negeri dan perkembangan pasar mencegah jangan sampai angka tersebut melampaui double digit atau melebihi 10 persen.

Dalam hal ini Pemerintah dihadapkan pada masalah pencapaian sasaran antara berupa :

- terkendalinya jumlah uang yang beredar. 
- mantapnya kepercayaan terhadap rupiah.

- terkendalinya tingkat suku bunga.

- terhimpunnya dana masyaràkat yang nganggur.

- terangsangnya kegiatan investasi.

Adapun gejala meningkatnya angka inflasi yang mendekati double digit erat kaitannya dengan situasi akhirakhir ini, dimana peningkatan dana yang terkumpul tidak diimbangi dengan penyaluran dana dengan tingkat yang setara. Kondisi tersebut disebabkan oleh hal-hal berikut :

- dana yang terkumpul kebanyakan berjangka pendek.

- biaya pengumpulan dana relatif mahal, sehingga harus disalurkan dengan biaya yang mahal pula.

- perbankan lebih suka menyalurkan dana yang berasal dari Kredit Likuiditas Bank Indonesia (KLBI), sedangkan dana yang dihimpun dari masyarakat digunakan untuk membeli Sertifikat Bank Indonesia (SBI).

- daya tarik pasar modal yang relatif lebih murah dalam biaya dana ternyata lebih disukai oleh pengusaha daripada harus meminjam ke bank - dana masyarakat yang terkumpul di bank tidak terlalu membantu investasi riil tetapi lebih banyak dilarikan ke pasar uang dan perdagangan Valuta Asing.

Bukti bahwa sektor riil tidak dapat mengikuti peningkatan permintaan agregat adalah terjadinya kasus kelangkaan komoditi tertentu di pasaran akibat proyeksi kebutuhan yang keliru. Kasus hilangnya suplai semen beberapa waktu yang lalu, men- dorong Pemerintah untuk menghentikan ekspor semen, demikian juga dengan kasus kurangnya suplai kendaraan niaga mengakibatkan Pemerintah membuka kran impor kendaraan tersebut. Kasus-kasus tersebut membuktikan bahwa pemanfaatan dana yang dihimpun dari masyrakat belum cukup membantu investasi sektor riil.

\section{KEBIJAKSANAAN UANG KETAT}

Dari hasil yang diperoleh melalui berbagai paket deregulasi yang dijalankan Pemerintah untuk mendukung kebijaksanaan moneter dan kebijaksanaan perekonomian pada umumnya, perlu terus dikembangkan usaha untuk mendorong dicapainya hasil yang positip di satu pihak dan mengatasi dampak negatip di lain pihak. Dengan adanya dampak negatip dari hasil mobilisasi dana masyarakat berupa inflasi yang dinilai cukup tinggi, maka Otoritas Moneter kita berusaha mencegah dan mengatasi agar inflasi tidak semakin tinggi, melainkan harus ditekan sampai ke tingkat yang aman dengan pertimbangan bahwa diperkirakan efek inflasi diatas $10 \%$ jauh lebih buruk daripada lambannya laju pertumbuhan akibat naiknya tingkat bunga. Oleh karena itulah Otoritas Moneter kita memberlakukan Kebijaksanaan Uang Ketat (Tight Money Policy), yang meliputi pembatasan atas penambahan jumlah uang yang beredar sesuai dengan kebutuhan pembiayaan sektor-sektor ekonomi produktif dan sekaligus memelihara stabilitas moneter. 
Dalam kebijaksanaan uang ketat ini Bank Indonesia melakukan tindakan sebagai berikut :

1. Penghapusan sebagian besar kredit likuiditas yang sudah dikeluarkan kepada dunia perbankan dengan jalan menarik kembali kredit tersebut secara bertahap tetapi pasti.

2. Kontraksi moneter, yaitu berupa penarikan rupiah dari peredaran.

3. Operasi Pasar dengan jalan menjual Sertifikat Bank Indonesia (SBI) yang menawarkan bunga cukup tinggi.

Menurut keterangan dari Bank Indonesia, dari pinjaman likuiditas total sebesar Rp. 10 trilyun, Bank Sentral baru menarik kembali Rp. 2,2 trilyun. Sedang sisanya sebesar Rp. 7,8 trilyun akan ditarik dalam jangka 10 tahun secara bertahap.

Tindakan-tindakan tersebut pada hakekatryya untuk mengurangi jumlah uang yang beredar di masyarakat untuk menekan inflasi sekaligus mempertahankan kepercayaan masyarakat terhadap rupiah dengan menjamin kestabilan nilai uangnya.

Disamping ditempuh dengan jalan absorpsi rupiah, kebijaksanaan uang ketat dapat lebih efektif lagi apabila diikuti dengan kredit selektif. Dalam hal ini, pemberian kredit harus benarbenar diarahkan pada kegiatan produktif di sektor riil yang menghasilkan komoditi yang sangat dibutuhkan masyarakat. Dengan kata lain untuk menekan inflasi yang terjadi, perlu meningkatkan pasokan suplai barang baik melalui produksi sendiri maupun impor.
Akibat kebijaksanaan uang ketat adalah suku bunga pinjaman menjadi tinggi, karena sektor perbankan harus memberi rangsangan bunga yang tinggi, demikian pula dalam menghimpun dananya. Akibat selanjutnya iklim investasi menjadi lesu.

Disamping itu, suku bunga yang tinggi dapat mendorong masuknya dana luar negeri, sehingga akan berpengaruh positip pada Neraca Pembayaran. Menghadapi hal-hal seperti itu, Pemerintah diharapkan berlaku fleksibel dalam menjalankan kebijaksanaan uang ketat ini. Apabila tingkat inflasi berhasil ditekan di bawah $10 \%$ (sebagai tingkat yang dikhawatirkan Pemerintah) maka Pemerintah dapat melonggarkan kebijaksanaan uang ketatnya. Sehingga pada akhirnya Pemerintah dapat menggairahkan kegiatan perekonomian dan menjaga kestabilan moneter sebagai sasaran akhir dari kebijaksanaan moneter.

Dari informasi terakhir, ternyata Pemerintah berhasil menekan inflasi sebesar $9,57 \%$ sampai dengan Desember 1990, berarti untuk sementara kebijaksanaan uang ketat dinilai berhasil. Disamping itu Pemerintah mengisyaratkan bahwa kebijaksanaan uang ketat akan dilonggarkan apabila tercapai kondisi tingkat inflasi ratarata bulanan tahun 1991 sebesar $0,50 \%$.

\section{PENUTUP}

Melalui deregulasi, secara umum Pemerintah berusaha menciptakan suatu momentum kepada pelakupelaku ekonomi, terutama sektor 
swasta untuk meningkatkan peranannya dalam perekonomian nasional. Hal itu sebagai konsekuensi logis dari menurunnya kemampuan pemerintah dalam membiayai pembangunan nasional, disamping tuntutan perkembangan era globalisasi juga menghendaki demikian.

Pesatnya dana masyarakat yang berhasil dihimpun oleh perbankan antara lain disebabkan karena tabungan masyarakat benar-benar meningkat akibat membaiknya perekonomian, penurunan cadangan minimum (reserve requirement) pada dunia perbankan dari $15 \%$ menjadi $2 \%$, penambahan jaringan kerja dengan pembukaan bank baru dan kantor cabang bank sehingga kemampuan bank bertambah, bank bebas meminjam dana luar negeri tanpa ada jumlah yang dapat di SWAP kan ke Bank Indonesia.

Deregulasi sektor moneter telah membawa manfaat di satu pihak, berupa terhimpunnya . dana masyarakat yang begitu besar untuk pembiayaan pembangunan dan investasi. Sehingga deregulasi telah membawa sektor moneter ke arah yang lebih efisien dan mandiri. Mekanisme pasar telah mulai berkembang sehingga kebijaksanaan moneter lebih bersifat tidak langsung, artinya pengendalian moneter dilakukan melalui mekanisme pasar.

Di lain pihak deregulasi tersebut juga berdampak negatip berupa meningkatnya tingkat inflasi yang cukup mengkhawatirkan, sehingga mendorong Pemerintah memberlakukan kebijaksanaan uang ketat untuk mengerem inflasi tersebut.

Dari hasil pengamatan sementara terhadap deregulasi sektor moneter, ternyata dirasakan ada kesenjangan/ketidakseimbangan antara sektor moneter paska deregulasi dengan sektor riil yang belum disentuh deregulasi.

Sedangkan kebijaksanaan uang ketat hanya berpengaruh pada sisi permintaan, padahal inflasi juga berasal dari penawaran (cost push inflation), dan kebijaksanaan uang ketat itu lebih bersifat sementara, oleh karena itu kiranya sudah tiba saatnya Pemerintah melakukan Deregulasi Sektor Riil untuk melengkapi Deregulasi Sektor Moneter agar tercapai keseimbangan antara pasar uang dan pasar barang. Dalam jangka panjang deregulasi sektor riil perlu diupayakan terus, karena keberhasilan deregulasi kedua sektor ini akan sangat membantu keberhasilan pembangunan ekonomi Indonesia.

\section{REFERENSI}

Anwar Nasution, Tinjauan Ekonomi Atas Dampak Paket Deregulasi Tahun 1988 pada Sistem Keuangan Indonesia, Gramedia, Jakarta-1990.

Boediono, Ekonomi Moneter, BPFE, Yogyakarta 1986.

Nopirin, "Kebijaksanaan Moneter di Indonesia" Suara Merdeka, edisij 7-8 Januari 1991.

Syamsuddin Mahmud, "Berapa Jumlah Uang dalam Peredaran ?" Kompas, edisi 16 Februari 1991 